\title{
Ilmenite-bearing mantle parageneses from kimberlite pipes
}

\author{
N.V. Alymova ${ }^{1}$, S.I. Kostrovitsky ${ }^{1}$, D.A. Yakovlev ${ }^{1}$, S.S. Matsyuk ${ }^{3}$, L.F. Suvorova ${ }^{1}$, \\ L.V. Solov'eva ${ }^{2}$
}

1- Institute of Geochemistry SB RAS, Favorskyi str, 1 a, Irkutsk, Russia

2- Institute of the Earth's Crust SB RAS , Lermontov str, 128, Irkutsk, Russia

3- Institute of Geochemistry, Mineralogy and Ore Formation, Kiev, Ukraine

Ilmenite-bearing varieties are scarce among mantle inclusions, found in kimberlite pipes of the Yakutian Province. We studied the composition of the representative collection of samples (over 50) of ilmenite xenoliths, forming a wide spectrum of petrographic varieties, including dunites, harzburgites, wehrlites, lherzolites, pyroxenites, eclogites, websterites, glimmerites from pipes Mir (Malya Botuobia field), Udachnaya, Dalnya (Daldyn field), Obnazhennaya, Sludyanka, Poiskovaya (Kuoika field).

Below we briefly describe principal features of chemical composition of rock-forming minerals and give an estimation of PT-parameters of crystallization.

Silicates demonstrate as a rule high $\mathrm{FeO}$ content, relatively low $\mathrm{Cr}_{2} \mathrm{O}_{3}$ and high $\mathrm{TiO}_{2}$ concentrations.

Olivine $(\mathrm{Ol})$ is characterized by high iron content: its average composition corresponds to the concentration as $13,8 \%$ of fayalite minal, varying within 9,3 - $18 \%$. Deep-seated xenoliths without ilmenite contain high-magnesium $\mathrm{Ol}$, as a rule, with 6 $-12 \%$ of fayalite minal.

Garnet (Gar) demonstrates high FeOtotal (from $10-12$ to 18,32 wt. \%) and wide variations in concentrations of others oxides $\left(0,12-1,44\right.$ wt. $\% \mathrm{TiO}_{2}$, 0,19-6,55 wt. $\% \mathrm{Cr}_{2} \mathrm{O}_{3}$ ).

Figurative points of $\mathrm{Gar}$ composition in $\mathrm{CaO}$ $\mathrm{Cr}_{2} \mathrm{O}_{3}$ plot (Sobolev, 1974) are mainly concentrated close to the lherzolite trend (Fig. 1A).

Gar from different pipes is characterized by wide variations in $\mathrm{TiO}_{2}$ content (fig. 1b) at relatively slight variations in magnesium content (69 - 81\%). Despite a significant range in $\mathrm{TiO}_{2}$ variations in Gar of Sludyanka pipe $(0,12-1,44$ wt. \%), the basic part of the investigated grains is grouped in the most low-titanium area (Fig. 1B). Garnet with higher titanium concentration (0,3-0,5 wt. \%) is found in Obnazhennaya pipe; and Gar demonstrating the highest titanium content $\left(0,6<\mathrm{TiO}_{2}<1,2\right.$ wt. \%) is observed in Udachnaya and Poiskovaya pipes.

Clinopyroxene (Cpx) includes subcalcium diopsides, diopsides, low-chromium diopsides (by Stephens, Dawson, 1977) and is characterized by the increased concentrations of $\mathrm{FeO}(2,77-6,12$ wt. \%) and $\mathrm{TiO}_{2}\left(0,19\right.$ - 1,06 wt. \%), low $\mathrm{Cr}_{2} \mathrm{O}_{3}(0,15-1,10$ wt. \%) content.

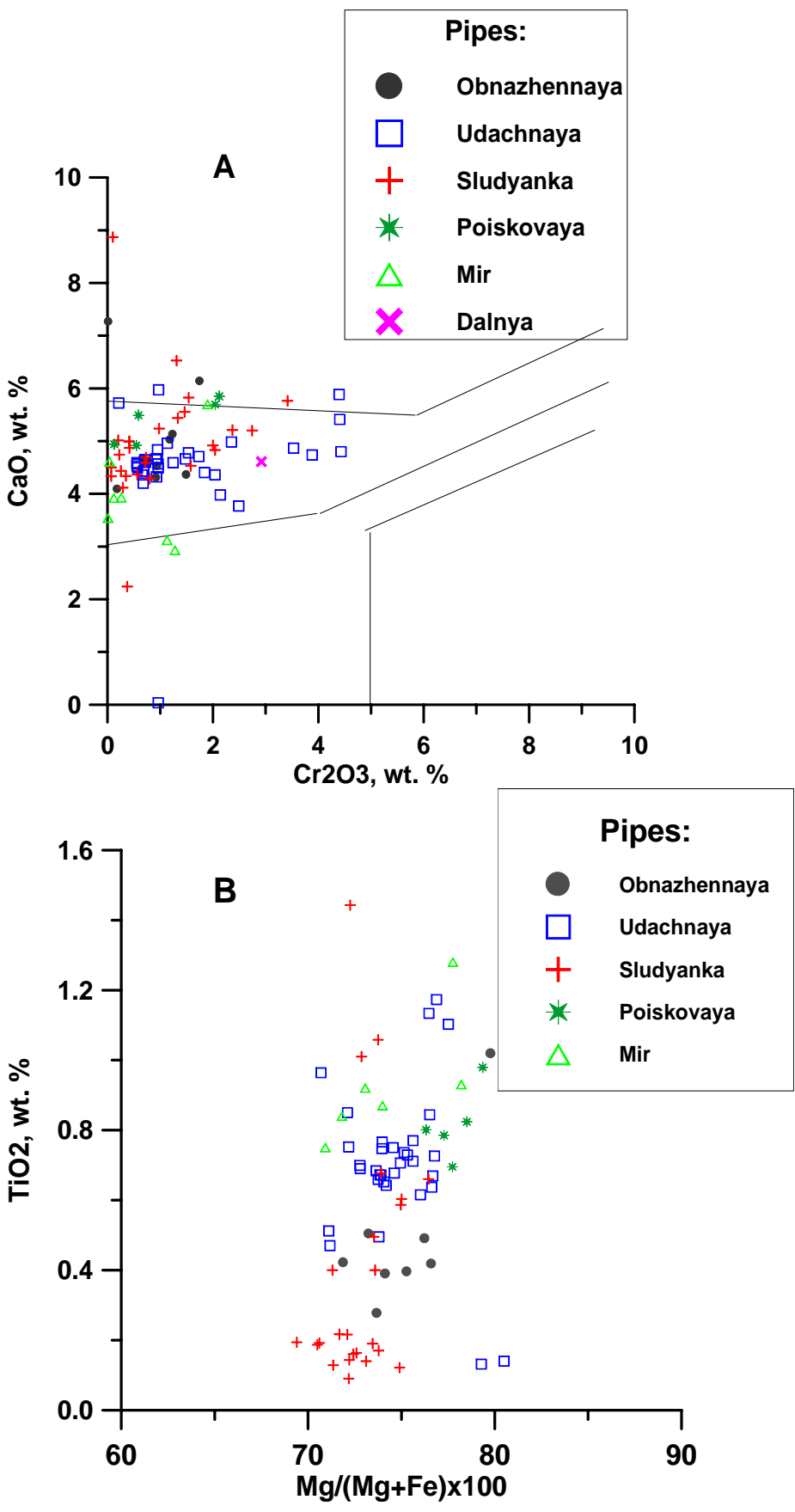

Fig. 1. $\mathrm{CaO}-\mathrm{Cr}_{2} \mathrm{O}_{3}$ (A) и $\mathrm{TiO}_{2}-\mathrm{Mg} /(\mathrm{Mg}+\mathrm{Fe})$ (В) dependences for Gar from ilmenite-containing xenolith. 
Cpx from ilmenite-containing parageneses as opposed to ilmenite-free ones demonstrate low $\mathrm{Cr}_{2} \mathrm{O}_{3}$ (0-1,1wtc. \% and 0,8-2,2 wt. \%, accordingly) and magnesium (81-90\% and 90-96\%, correspondingly) contents.

Cpx from ilmenite xenolith of some pipes shows the difference in the composition. Cpx from Mir pipe is marked by minimum $\mathrm{Cr}_{2} \mathrm{O}_{3}$ (to 0,2 wt. \%), magnesium content (to $86 \%$ ) and calcium coefficient (36-43\%). Cpx from Sludyanka pipe shows the maximum calcium content $(45-50 \%)$, and that from Obnazhennaya pipe possesses low $\mathrm{Cr}_{2} \mathrm{O}_{3}$ (mainly to 0,5 wt. \%) and increased calcium concentration (43-48 $\%$ ), Cpx from Udachnaya pipe has low calcium content (35-45\%) and wide variations in $\mathrm{Cr}_{2} \mathrm{O}_{3}$ abundance (fig. 2).

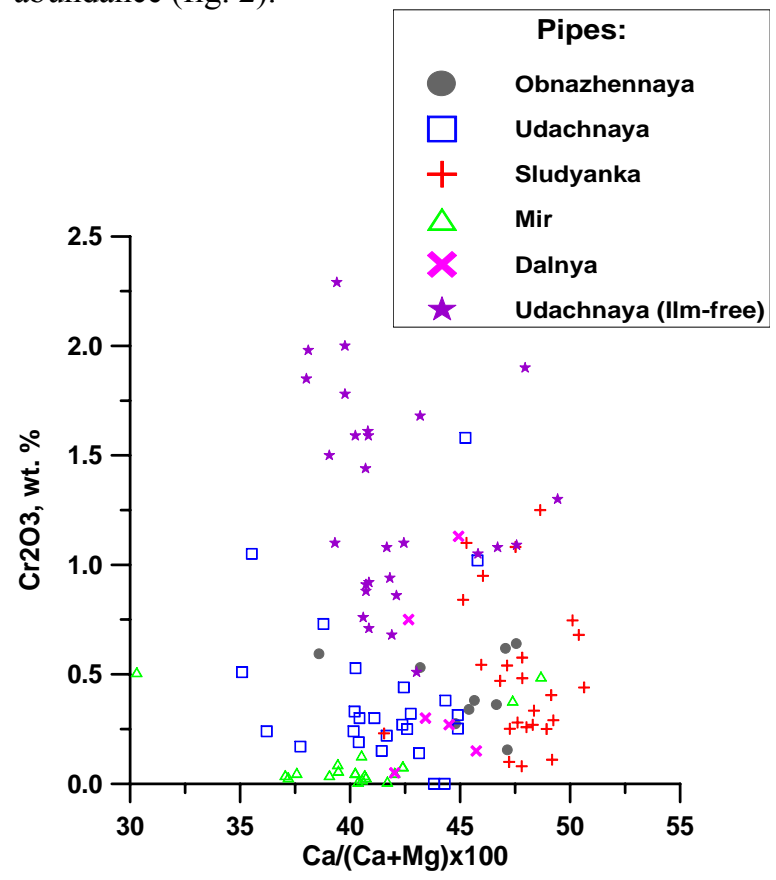

Fig.2. $\mathrm{Cr}_{2} \mathrm{O}_{3}-\mathrm{Ca} /(\mathrm{Ca}+\mathrm{Mg}) \times 100$ dependence for $\mathrm{Cpx}$ from ilmenite-containing xenoliths.

Fig. 3 shows the tendency towards increase of calcium coefficient in a number of pipes (Udachnaya, Mir, Dalnya, Obnazhennaya, Sludyanka) that indicates the decrease in temperature of $\mathrm{Cpx}$ crystallization in these kimberlite bodies.

Orthopyroxene (Opx) includes enstatite, hightitanium bronzites and is characterized by wide variations of composition: $\mathrm{TiO}_{2}(0,07-0,63$ wt. \%), $\mathrm{Cr}_{2} \mathrm{O}_{3}\left(0,01-0,36\right.$ wt. \%), $\mathrm{CaO}\left(0,3-1,47\right.$ wt. \%), $\mathrm{Na}_{2} \mathrm{O}$ (0,01-0,68 wt. \%), $\mathrm{Al}_{2} \mathrm{O}_{3}(0,29-4,52$ wt. \%).

Opx from ilmenite-containing xenoliths of Sludyanka pipe is divided into two groups taking into account $\mathrm{Al} 2 \mathrm{O} 3$ content (fig. 4): 1) with relatively low alumina content $(0,5-1,5$ wt. \%) and 2) with high alumina content $(2,2-3,1$ wt. $\%)$.

Fields of composition of the first group of orthopyroxenes from Sludyanka, and Obnazhennaya pipes as well as fields of the second group and orthopyroxene from Poiskovaya pipe are overlapped. Nevertheless, considering $\mathrm{A} 12 \mathrm{O} 3$ content, the majority of imenite-containing rocks are low baric.

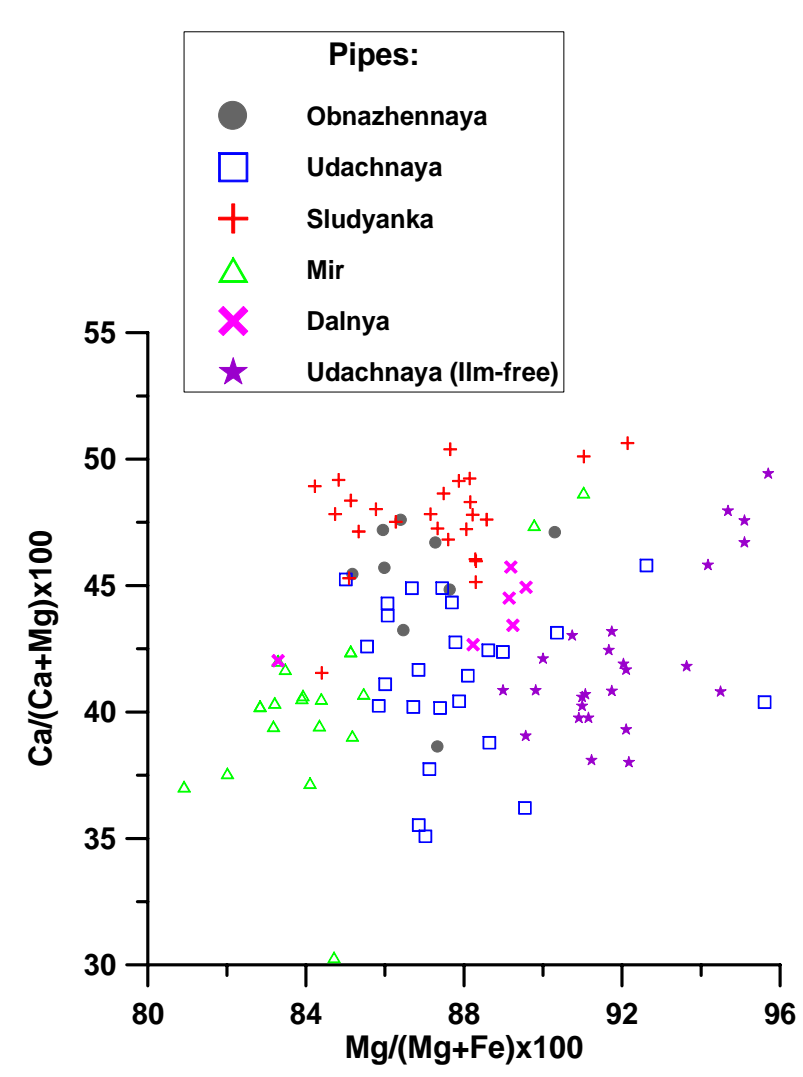

Fig. 3. $\mathrm{Ca} /(\mathrm{Ca}+\mathrm{Mg}) \times 100-\mathrm{Mg} /(\mathrm{Mg}+\mathrm{Fe}) \times 100$ dependence for $\mathrm{Cpx}$ from ilmenite-containing xenoliths.

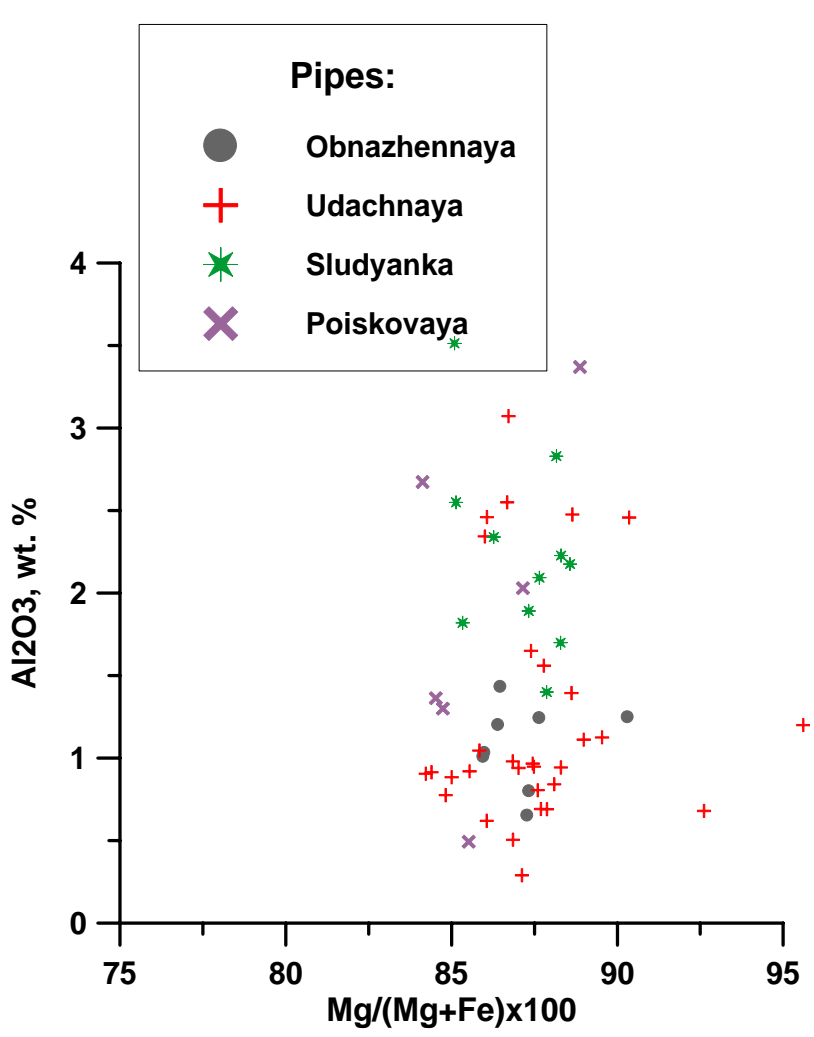

Fig. 4. $\mathrm{Al}_{2} \mathrm{O}_{3}-\mathrm{Ca} /(\mathrm{Ca}+\mathrm{Mg}) \times 100$ dependence for $\mathrm{Opx}$ from ilmenite-containing xenoliths. 
Picroilmenite (Ilm) is irregularly distributed in xenoliths: Obnazhennaya pipe shows very low Ilm content (from individual grains to 3-5 \%) while in mantle xenoliths from Sludyanka and Obnazhennaya pipes Ilm reaches high values (to 30-35\%).

Ilm from xenoliths possesses wide variations of $\mathrm{TiO}_{2}\left(43,30-57,32\right.$ wt. \%), $\mathrm{Al}_{2} \mathrm{O}_{3}(0,00-2,09), \mathrm{Cr}_{2} \mathrm{O}_{3}$ $(0,32-5,28$ wt. \%), $\mathrm{MgO}(5,42-15,22$ wt. \%), $\mathrm{FeO}$ $(26,86-56,69$ wt. $\%), \mathrm{Mg} /(\mathrm{Mg}+\mathrm{Fe}) * 100(26,31-49,01)$ values.

The composition of ilmenites from kimberlites and Ilm xen as exemplified by Udachnaya pipe is shown to have clear difference. The ilmenite from xenoliths shows higher magnesium content and low concentration of hematite minal as compared with ilmenites from kimberlites, i.e. it was crystallized in more reduced conditions (fig. 5).

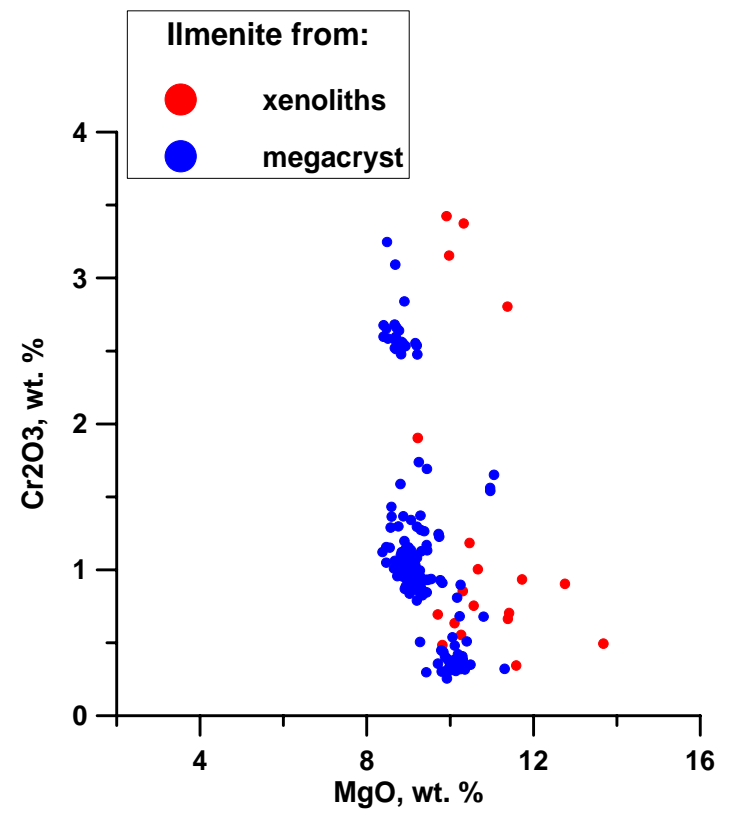

Fig. 5. $\mathrm{Cr}_{2} \mathrm{O}_{3}-\mathrm{MgO}$ dependence for Ilm megacrysts and ilmenite-containing xenoliths from pipe Udachna.

Picroilmenites from xenoliths and kimberlites of Sludaynka pipe demonstrate similar compositions. These data suggest that in the south diamond-bearing fields the major part of picroilmenite from kimberlites is not associated with the disintegration of ilmenitebearing mantle rocks, while for ilmenites from kimberlites of the north fields the disintegration had a visible role.

Distribution of rare earth elements in garnets and clinopyroxenes from Ilm xen indicates a common high-iron and high-titanium paragenesis as well as equilibrium crystallization and magmatic origin.

We calculated PT-conditions of forming rocks via geothermobarometers: Brey \& Kohler (1990), Krogh (1988), Nickel \& Green (1985) using on the representative database of chemical composition of Ilm xen minerals (fig. 6). Xenoliths from pipes of the north fields (Sludaynka and Obnazhennaya) are marked by relatively lowtemperature and low-pressure crystallization conditions. Xenoliths from the
Poiskovaya pipe turned out to be high-temperature. Ilmenite xenoliths from the Udachnaya pipe are highpressure formations.

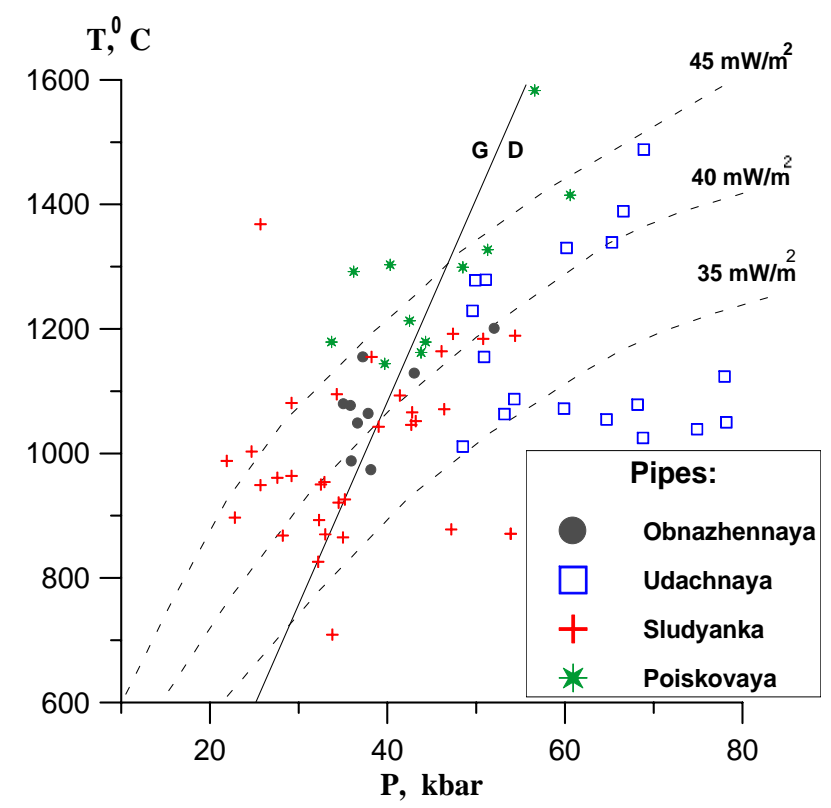

Fig. 6. PT-diagram of ilmenite xenolith crystallization.

The studies are supported by RFBR № 06-0564981 and 06-05-64756.

\section{References}

Brey G.P., Kohler T., Nickel K.G., 1990. Journal of petrology, 31, 1353-1378.

Krogh E.J., 1988. The garnet-clinopyroxene Fe-Mg geothermometer - a reinterpretation of existing experimental data. Contrib. Mineral. Petrol., 99, 4448.

Nickel K.G., Green D.H., 1985 Empirical geothermobarometry for garnet peridotites and implications for the nature of the lithosphere, kimberlites and diamonds. Earth Planet .Sci. Lett., 73, 158-170.

Sobolev N.V., 1974. Deep-seated inclusions in kimberlites and the problem of the upper mantle composition. Novosibirsk, Nauka, 261 pp.

Stephens W.E., Dawson J.B., 1977. Statistical comparison between pyroxenes from kimberlites and their associated xenoliths. Journal of geology, 85, 4333449. 